\title{
Insulin receptor dephosphorylation by phosphotyrosine phosphatases obtained from insulin-resistant obese mice
}

\author{
C. Olichon-Berthe, S. Hauguel-De Mouzon, P. Péraldi, E. Van Obberghen, Y. Le Marchand-Brustel \\ INSERM U 145, Faculté de Médecine, Nice, France
}

Summary To study the possible involvement of phosphotyrosine phosphatases in insulin resistance, the ability of cytosolic and membrane preparations to dephosphorylate insulin receptors was examined in lean and goldthioglucose-treated insulin-resistant and obese mice. Preparations were obtained from liver, heart, diaphragm and hindleg muscle and their phosphotyrosine phosphatase activities were measured using an immunoenzymatic assay with phosphorylated insulin receptors as substrate. Liver cytosolic and particulate phosphotyrosine phosphatases were more potent than preparations from other tissues and were able to almost completely dephosphorylate the insulin receptor in a dose- and time-dependent manner. No change was observed in cytosolic and membrane-asso- ciated phosphotyrosine phosphatases in liver, diaphragm, and heart of obese mice compared with lean mice. In contrast, cytosolic, but not membrane-associated, phosphotyrosine phosphatase activity was decreased in hindleg muscles of obese mice. These results suggest that the regulation of phosphotyrosine phosphatases is tissue-specific. In addition, alterations in total phosphotyrosine phosphatase activity do not appear to play an important role in insulin resistance in all tissues of obese mice, although specific changes cannot be excluded. [Diabetologia (1994) 37: 56-60]

Key words Insulin resistance, experimental obesity, phosphotyrosine phosphatase, muscle, liver.
Insulin resistance linked to obesity results from a series of alterations at the receptor level and at post-receptor steps of insulin action. One of those defects is the decreased receptor kinase activity which occurs in muscle, which has been substantiated in animal models [1] and in human syndromes [2]. The intrinsic tyrosine kinase activity of the receptor depends on its state of phosphorylation resulting from a balance between tyrosine phosphorylation and dephosphorylation. The function of protein tyrosine phosphatases (PTP-ases) is thought to counterbalance the action of protein tyrosine kinases allowing the regulation of the phosphotyrosine content of proteins involved in signal transduc-

Received: 19 April 1993

and in revised form: 4 August 1993

Corresponding author: Dr. Y.Le Marchand-Brustel, INSERM U 145, Faculté de Médecine, Avenue de Vallombrose, F-06107 Nice Cédex 02, France tion, such as the insulin receptor [3]. This view is supported by the observation that microinjection of PTPases into oocytes inhibits some of the actions of insulin [4]. PTP-ases have been purified and cloned from a variety of tissues and cell lines [5-9]. Two main classes of PTP-ases have been identified thus far: the first includes enzymes with a receptor-like structure, which are associated to membranes; the second consists of soluble enzymes [10,11]. Since PTP-ases counteract tyrosine kinase activities, the defect in insulin receptor tyrosine kinase activity found in insulin resistance linked to obesity could result from alterations in the PTP-ase activity. To determine a possible involvement of PTP-ases in the obese hyperinsulinaemic syndrome, we prepared particulate and cytosolic PTP-ases from different insulin-responsive tissues of lean and obese mice and tested their ability to dephosphorylate the insulin receptor. 
Table 1. Characteristics of the animals

\begin{tabular}{lcc}
\hline & Lean mice & Obese mice \\
\hline Weight $(\mathrm{g})$ & $45.6 \pm 0.8$ & $66.5 \pm 1.4$ \\
Plasma glucose $(\mathrm{mmol} / \mathrm{l})$ & $11.1 \pm 0.3$ & $13.3 \pm 0.4$ \\
Plasma insulin $(\mathrm{nmol} / \mathrm{l})$ & $0.28 \pm 0.03$ & $2.27 \pm 0.48$ \\
Tissue wet weight $(\mathrm{g})$ & & \\
Liver & $2.12 \pm 0.16$ & $3.54 \pm 0.30$ \\
Diaphragm & $0.102 \pm 0.010$ & $0.132 \pm 0.005$ \\
Heart & $0.214 \pm 0.008$ & $0.252 \pm 0.008$ \\
\hline
\end{tabular}

Fed lean and obese mice were used at 20-30 weeks of age. Blood samples were used to measure glucose and insulin levels. Thereafter, liver, diaphragm, heart and hindleg muscles were removed for cytosolic and membrane preparations, as described in Materials and methods.

Values are presented as mean \pm SEM of 8-10 animals.

$p<0.01$ or less for all comparisons lean vs obese mice

\section{Materials and methods}

\section{Materials}

HEPES, ATP, Triton X-100, N-acetyl-D-glucosamine, dithiothreitol, protease inhibitors were from Sigma (St Louis, Mo., USA). The Bradford protein assay was from Bio-Rad Laboratories (Richmond, Calif., USA). All other reagents were of the highest purity available. Sheep antiphosphotyrosine antibody was produced in our laboratory and $\gamma$-globulins $(4 \mu \mathrm{g}$ protein/ml) purified by affinity chromatography were used in all experiments. Peroxidase-conjugated rabbit antisheep antibody was purchased from Dako (Glostrup, Denmark). Plastic ware for the immunoassay was from Nunc (Copenhagen, Denmark).

\section{Animals}

Male Swiss albino mice were provided laboratory chow (Usine d'Alimentation Rationelle, Villemoisson, Epinay/Orge, France) ad libitum, and maintained at $22^{\circ} \mathrm{C}$ on a 12-h light/dark cycle until the time of death. Mice were rendered obese by goldthioglucose injection at 3 weeks of age and were used at 6 months of age, when obesity had reached a plateau $[12,13]$. Mice were anaesthetized with pentobarbitone sodium $(50 \mathrm{mg} / \mathrm{kg}$ i.p.), and blood samples were withdrawn from the inferior vena cava. Plasma samples were used for the determination of glycaemia and insulinaemia as previously described $[12,13]$. Animals were then killed by cervical dislocation, and tissues (liver, diaphragm, heart, and hindleg muscles) were rapidly dissected for membrane and cytosolic preparations.

\section{Membrane-associated and cytosolic phosphatase preparations}

Membrane-associated and cytosolic phosphatase preparations were obtained as previously described $[14,15]$. Tissues were homogeneized in $250 \mathrm{mmol} / \mathrm{l}$ sucrose, $25 \mathrm{mmol} / 1$ Hepes, $15 \mathrm{mmol} / \mathrm{l}$ $\beta$-mercaptoethanol, $1 \mathrm{mmol} / \mathrm{l}$ phenylmethylsulphonylfluoride and $100 \mathrm{U} / \mathrm{ml}$ Trasylol, $\mathrm{pH}$ 7.2. Following the first centrifugation $(600 \mathrm{~g}, 20 \mathrm{~min})$ to eliminate the fat layer, homogenates were centrifuged at $12,000 \mathrm{~g}$ for $20 \mathrm{~min}$. $\mathrm{NaCl}(0.1 \mathrm{~mol} / \mathrm{l})$ and $\mathrm{MgCl}_{2}$ $(0.2 \mathrm{mmol} / \mathrm{l})$ were added to the supernatants which were centrifuged at $100,000 \mathrm{~g}$ for $30 \mathrm{~min}$. The supernatants obtained after this last step were considered to be the cytosolic fractions. The remaining pellets, corresponding to microsomal fractions, were solubilized with $1 \%$ Triton $\mathrm{X}-100$ in $25 \mathrm{mmol} / \mathrm{l}$ Hepes buffer and centrifuged at $100,000 \mathrm{~g}$ for $30 \mathrm{~min}$. The final supernatants were used to measure membrane-associated phosphatase activity. Protein content of the preparations was determined by the BioRad assay with bovine serum albumin as standard.

\section{Measurement of tyrosine phosphatase activity by immunoenzymatic assay}

The measurements of PTP-ase activity were performed using an immunoenzymatic method with phosphorylated insulin receptors as substrate [14]. Briefly, human insulin receptors, partially purified from a cell line transfected with insulin receptor cDNA and expressing $10^{6}$ receptors per cell [16], were autophosphorylated and coated in a microtitre plate (250 ng protein/well). Dephosphorylation was initiated in the plate by the addition of extracts containing phosphatases. Following incubation $\left(30 \mathrm{~min}\right.$ at $\left.22^{\circ} \mathrm{C}\right)$ and washes, antiphosphotyrosine and peroxidase-conjugated rabbit anti-sheep antibodies were successively added [14]. Finally, orthophenylenediamine dihydrochloride was used as a chromogene, and optical density (OD) readings were performed at $405 \mathrm{~nm}$ on an ELISA minireader (Dynatec MR700; Saint Cloud, France). PTP-ase activity was expressed as a percentage of receptor dephosphorylation, based on the OD ratios, where $0 \%$ corresponds to receptor incubation without PTP-ase.

\section{Statistical analysis}

Comparisons were performed using Student's $t$-test.

\section{Results}

Following goldthioglucose injection, mice were markedly obese, hyperinsulinaemic and moderately hyperglycaemic (Table 1) and were thus insulin-resistant. Obesity was accompanied by hepatomegaly, and increase in the weight of the heart and diaphragm muscles. We first assessed the particulate and cytosolic PTP-ase activity of liver from lean and obese mice [14, 17]. Insulin receptor dephosphorylation by hepatic microsomal fraction was dependent upon the incubation time and protein concentration (Fig. 1) both in lean and obese preparations. Particulate fractions were more potent than cytosolic preparations. There was no difference in hepatic particulate and cytosolic activities between lean and obese mice, at any protein concentration or incubation time.

The following muscle preparations were studied: heart, diaphragm, and hindleg muscles. All muscle preparations were able to dephosphorylate the insulin receptor, but to different extents (Table 2). Muscle preparations were less potent than liver extracts. In all tissues the PTP-ase activity was higher in microsomal than in cytosolic preparations. In particulate fractions from muscles (hindleg, heart and diaphragm), no significant difference was found in PTP-ase activities be- 

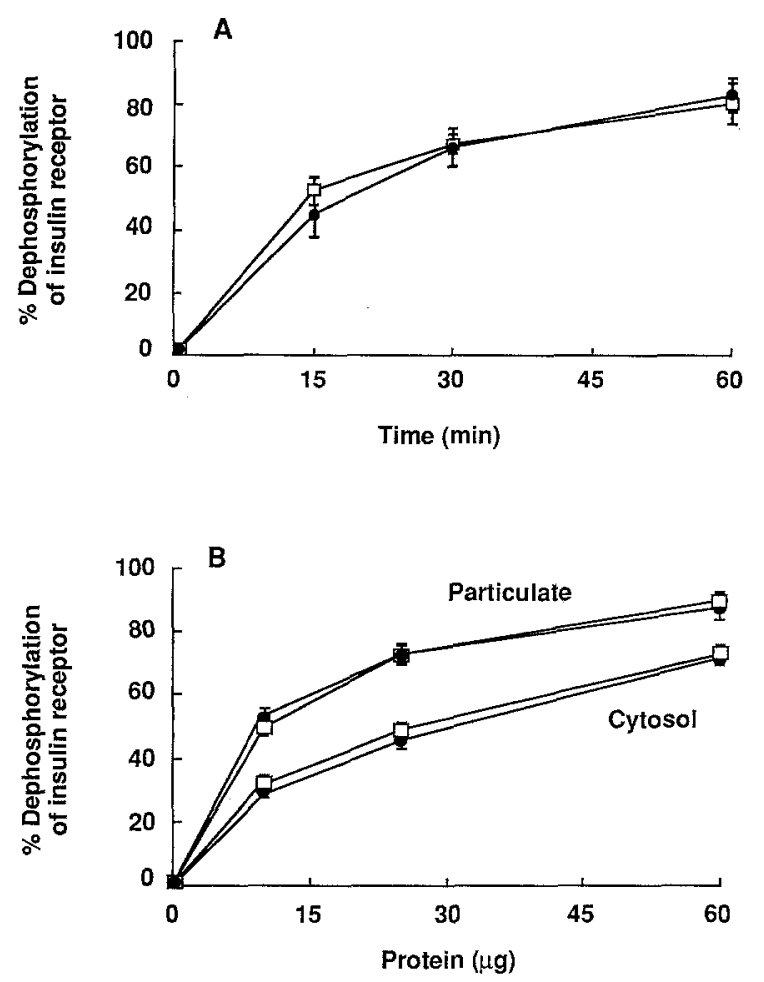

Fig. 1. (A, B) Time course and dose-response of insulin receptor dephosphorylation by hepatic phosphotyrosine phosphatases (PTP-ase). PTP-ase preparations were obtained from liver of lean ( $\square$ ) and obese ( $)$ mice as described in Materials and methods. PTP-ase activity was assessed using an immunoenzymatic assay with antibody to phosphotyrosine as a probe. Partially purified insulin receptors were prephosphorylated, adsorbed on microtitre plates. The immobilized receptors were then incubated with $25 \mu \mathrm{g}$ of microsomal proteins for various lengths of time (A) or with increasing amounts of cytosolic or particulate proteins for $30 \mathrm{~min}$ (B). Results are expressed as a percent of receptor dephosphorylation. Autophosphorylated receptors incubated in the absence of PTP-ases correspond to $0 \%$ dephosphorylation. Values are the mean \pm SEM obtained with six individual preparations

Table 2. Insulin receptor dephosphorylation by cytosolic and membrane fractions from different tissues of lean and obese mice

\begin{tabular}{lccccc}
\hline & \multicolumn{3}{l}{ Insulin receptor dephosphorylation } \\
& Membrane-associated & & Cytosolic & \\
\cline { 2 - 3 } \cline { 5 - 6 } Mice & Lean & Obese & & Lean & Obese \\
\hline Muscle & & & & \\
Hindleg & $67.9 \pm 1.0$ & $65.8 \pm 2.8$ & & $42.6 \pm 4.4$ & $27.9 \pm 4.1^{\text {a }}$ \\
Heart & $51.9 \pm 1.6$ & $56.6 \pm 2.7$ & & $43.1 \pm 1.7$ & $47.7 \pm 1.7$ \\
Diaphragm & $65.1 \pm 3.6$ & $59.4 \pm 4.9$ & & $39.5 \pm 3.0$ & $38.1 \pm 2.3$ \\
Liver & $90 \pm 3$ & $88 \pm 4$ & & $73.0 \pm 1.4$ & $71.7 \pm 1.8$ \\
\hline
\end{tabular}

Particulate and cytosolic fractions were prepared from lean and obese mice and the phosphotyrosine phosphatase activity was measured towards the phosphorylated insulin receptor with $50 \mu \mathrm{g}$ of protein as described in Materials and methods. Values are expressed as percent of insulin receptor dephosphorylation and are presented as mean $\pm S E M$ of results obtained with four to six individual preparations assayed in triplicate.

${ }^{a} p<0.01$ lean vs obese mice; $p=$ NS for all other comparisons

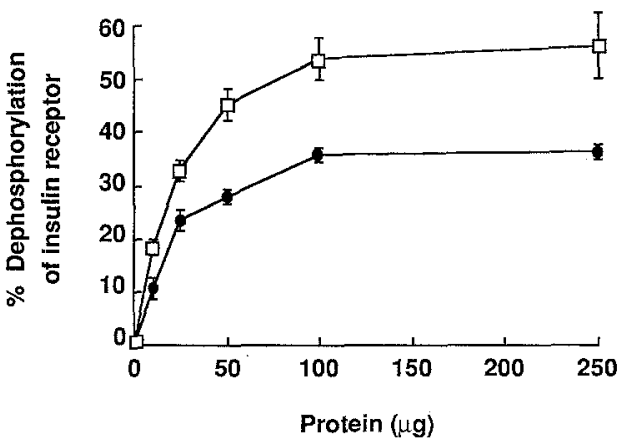

Fig.2. Insulin receptor dephosphorylation by cytosolic phosphotyrosine phosphatases (PTP-ases) from hindleg muscles of lean ( $\square$ ) and obese mice ( ). PTP-ase cytosolic preparations were prepared from hindleg muscles as described in Materials and methods. Dephosphorylation reactions were performed as described in Figure 1 with increasing amounts ( 0 to $250 \mu \mathrm{g})$ of cytosolic PTP-ases. Values are the mean \pm SEM obtained with four individual preparations

tween lean and obese mice (Table 2). By contrast, the ability of phosphotyrosine phosphatases to dephosphorylate insulin receptors was decreased in the cytosolic fraction obtained from hindleg muscles of obese mice compared to lean animals, whereas no difference was observed in cytosolic fractions from heart or diaphragm (Table 2). This decrease in PTP-ases from obese hindleg muscles was restricted to the cytosolic fraction, since no difference was observed at any of the protein concentrations used from the particulate fraction (data not shown). As shown in Figure 2, the dephosphorylation of insulin receptors by cytosolic PTPases from lean and obese animals was dependent upon the amount of protein, and was observed at all protein concentrations.

\section{Discussion}

Insulin resistance is commonly associated with obesity both in humans and rodents. The present study was conducted in mice rendered obese following injection of goldthioglucose, which induces hyperphagia, hyperinsulinaemia and insulin resistance [12]. This is associated with altered muscle glucose uptake, both in basal and insulin-stimulated conditions $[12,13]$. Previous studies have shown that this is a result of multiple alterations both at the receptor and postreceptor levels. One alteration is the defective insulin receptor autophosphorylation and tyrosine kinase activity described in muscle from obese mice [1] and in obese non-insulindependent diabetic patients [2]. The state of receptor autophosphorylation results from a balance between tyrosine phosphorylation and dephosphorylation. This led us to study PTP-ase activities in particulate and cytosolic fractions from different tissues of lean and obese mice, using prephosphorylated insulin receptors and an immunoenzymatic assay with antibodies to 
phosphotyrosine $[14,17]$. Dephosphorylation of insulin receptors measured by this assay was dependent upon the protein concentration and incubation time, and excludes a possible interference with serine-threonine phosphatases. Furthermore, a natural substrate, the insulin receptor, was used rather than artificial proteins or peptides [3].

Preparations from all insulin-responsive tissues investigated, possessed PTP-ase activities which were higher in microsomes than in cytosol, as reported in rats [17-20] and humans [21]. Liver extracts were the most potent, resulting in $90 \%$ and $73 \%$ insulin receptor dephosphorylation for microsomes and cytosol, respectively. In contrast, in hindleg muscle, a maximum of $55 \%$ dephosphorylation was obtained with $100 \mu \mathrm{g}$ of cytosolic proteins. Different tyrosine residues within the insulin receptor undergo phosphorylation during insulin stimulation. Our observation that muscle PTPase preparations are unable to completely dephosphorylate the phosphorylated insulin receptor in contrast to liver PTP-ase preparations could suggest that some "specific" PTP-ases present in liver are absent or inactive in muscle.

In hindleg muscles of obese mice, cytosolic PTP-ase activity was decreased at all protein concentrations compared to the preparations from lean animals. Thus, in insulin-resistant obese mice, a defect in the ability to dephosphorylate the insulin receptor was observed, but only in hindleg muscles and was restricted to the cytosolic fraction. No difference was observed in diaphragm, heart and liver. These results suggest that PTP-ases can be regulated in a tissue-specific manner. It was originally thought that an increase in PTP-ase activity might cause a decrease in tyrosine kinase activity of insulin receptor and thus contribute to insulin resistance. However, a reduced PTP-ase activity may also lead to altered insulin action if the dephosphorylation of some phosphotyrosine residues are obligatory steps in the insulin signalling. Conflicting results have been found in the literature using different models. For example, hepatic PTP-ase activity measured with a synthetic peptide was decreased in $\mathrm{db} / \mathrm{db}$ or ob/ob mice [20], but was unchanged in our study in experimentallyinduced obese mice with insulin receptor used as substrate. A diminution of PTP-ase activity was associated with a decreased insulin receptor autophosphorylation in livers of streptozotocin-diabetic animals in some studies [17], but not in others [18, 22]. A slight increase in particulate PTP-ase activity has been observed in muscle from insulin-resistant humans [21], while we observed a decrease in cytosolic PTP-ases from mouse hindleg muscle. Finally, in the alloxan diabetic rat, divergent results were obtained depending on the substrate used for assay $[18,23]$. Whether this discrepancy is the result of the insulin-resistant models with various blood glucose or insulin levels, the preparation of the subcellular fractions, or more likely the different substrates used for measuring the PTP-ase activity is not known. Clarification of these problems will require better knowledge of how the PTP-ases specifically act on the insulin receptor.

Acknowledgements. C.Olichon-Berthe was the recipient of fellowships from the French Association for the Study of Myopathy (AFM) and from the Wellcome Company (Paris). This work was supported by a grant from AFM, and received support from INSERM, University of Nice, and Région Provence Côte d'Azur, France.

\section{References}

1. Le Marchand-Brustel Y, Grémeaux T, Ballotti R, Van Obberghen $E$ (1985) Insulin receptor tyrosine kinase is defective in skeletal muscle of insulin-resistant obese mice. Nature 315: 676-679

2. Caro JF, Sinha MK, Raju SM et al. (1987) Insulin receptor kinase in human skeletal muscle from obese subjects with and without noninsulin dependent diabetes. J Clin Invest 79: 1330-1337

3. Lau KHW, Farley JR, Baylink DJ (1989) Phosphotyrosyl protein phosphatases. Biochem J 257:23-36

4. Cicirelli MF, Tonks NK, Diltz CD, Weiel JE, Fischer EH, Krebs EG (1990) Microinjection of a protein-tyrosine-phosphatase inhibits insulin action in Xenopus oocytes. Proc Natl Acad Sci USA 87: 5514-5518

5. Tonks NK, Diltz CD, Fischer EH (1988) Purification of the major protein-tyrosine-phosphatases of human placenta. $J$ Biol Chem 263: 6722-6730

6. Tonks NK, Diltz CD, Fischer EH (1988) Characterization of the major protein-tyrosine-phosphatases of human placenta. J Biol Chem 263: 6731-6737

7. Kaplan R, Morse B, Huebner Ket al. (1990) Cloning of three human tyrosine phosphatases reveals a multigene family of receptor-linked protein-tyrosine-phosphatases expressed in brain. Proc Natl Acad Sci USA 87: 7000-7004

8. Mosinger B Jr, Tillmann U, Westphal H, Tremblay ML (1992) Cloning and characterization of a mouse cDNA encoding a cytoplasmic protein-tyrosine-phosphatase. Proc Natl Acad Sci USA 89: 499-503

9. Cool DE, Tonks NK, Charbonneau H, Walsh KA, Fischer $\mathrm{EH}$, Krebs EG (1989) cDNA isolated from a human T-cell library encodes a member of the protein-tyrosine-phosphatase family. Proc Natl Acad Sci USA 86: 5257-5261

10. Fischer EH, Charbonneau H, Tonks NK (1991) Protein tyrosine phosphatases: a diverse family of intracellular and transmembrane enzymes. Science 253:401-406

11. Shen S-H, Bastien L, Posner BI, Chrétien P (1991) A proteintyrosine phosphatase with sequence similarity to the $\mathrm{SH} 2$ domain of the protein-tyrosine kinases. Nature 352: 736-739

12. Le Marchand Y, Freychet P, Jeanrenaud B (1978) Longitudinal study on the establishment of insulin resistance in hypothalamic obese mice. Endocrinology 102: 74-85

13. Le Marchand-Brustel Y, Jeanrenaud B, Freychet P (1978) Insulin binding and effects in isolated soleus muscle of lean and obese mice. Am J Physiol 234: E348-E358

14. Peraldi P, Hauguel-De Mouzon S, Alengrin F, Van Obberghen E (1992) Dephosphorylation of human insulin-like growth factor I (IGF-I) receptors by membrane-associated tyrosine phosphatases. Biochem J 285: 71-78

15. Roome J, O'Hare T, Pilch PF, Brautigan DL (1988) Protein phosphotyrosine phosphatase purified from the particulate fraction of human placenta dephosphorylates insulin and growth factor receptors. Biochem J 256: 493 -500 
16. Whittaker J, Okamoto AK, Thys R, Bell GI, Steiner DF, Hofmann CA (1987) High-level expression of human insulin receptor cDNA in mouse NIH 3 T3 cells. Proc Natl Acad Sci USA 84: 5237-5241

17. Hauguel-De Mouzon S, Peraldi P, Alengrin F, Van Obberghen E (1993) Alteration of phosphotyrosine phosphatase activity in tissues from diabetic and pregnant rats. Endocrinology 132: 67-74

18. Boylan JM, Brautigan DL, Madden J, Raven T, Ellis L, Gruppuso PA (1992) Differential regulation of multiple hepatic protein tyrosine phosphatases in alloxan diabetic rats. $\mathbf{J}$ Clin Invest 90: 174-179

19. Goldstein BJ, Meyerovitch J, Zhang WR et al. (1991) Hepatic protein-tyrosine phosphatases and their regulation in diabetes. Adv Protein Phosphatases 6: 1-17

20. Meyerovitch J, Rothenberg P, Shechter Y, Bonner-Weir S, Kahn CR (1991) Vanadate normalizes hyperglycemia in two mouse models of non-insulin-dependent diabetes mellitus. J Clin Invest 87: 1286-1294

21. McGuire MC, Fields RM, Nyomba BL et al. (1991) Abnormal regulation of protein tyrosine phosphatase activities in skeletal muscle of insulin-resistant humans. Diabetes 40: 939-942

22. Begum N, Sussman KE, Draznin B (1991) Differential effects of diabetes on adipocyte and liver phosphotyrosine and phosphoserine phosphatase activities. Diabetes 40: 16201629

23. Gruppuso PA, Boylan JM, Posner BI, Faure R, Brautigan DL (1990) Hepatic protein phosphotyrosine phosphatase. Dephosphorylation of insulin and epidermal growth factor receptors in normal and alloxan diabetic rats. J Clin Invest 85 : $1754-1760$ 